\title{
SOIL PHOSPHORUS FRACTIONS IN SANDY SOILS AMENDED WITH CATTLE MANURE FOR LONG PERIODS ${ }^{(1)}$
}

\author{
Sandra Regina da Silva Galvão ${ }^{(2)}$ \& Ignacio Hernan Salcedo ${ }^{(3)}$
}

\begin{abstract}
SUMMARY
Phosphorus fractions were determined in soil samples from areas fertilized or not with farmyard cattle manure (FYM) and in samples of FYM used in the semi-arid region of Paraiba state, Brazil. Soil samples were taken from the 0-20; 20-40 and 40-60 cm layers of 18 cultivated areas, which, according to interviews with farmers, had been treated with 12 to $20 \mathrm{t} \mathrm{ha}^{-1} \mathrm{FYM}$ annually, for the past 2 to 40 years. Soil samples were also collected from four unfertilized pasture areas as controls. Phosphorus in the soil samples was sequentially extracted with water $\left(\mathrm{P}_{\mathrm{w}}\right)$, resin $\left(\mathrm{P}_{\text {res }}\right), \mathrm{NaHCO}_{3}\left(\mathrm{Pi}_{\text {bic }}\right.$ and $\left.\mathrm{Po}_{\text {bic }}\right), \mathrm{NaOH}\left(\mathrm{Pi}_{\text {hid }}\right.$ and $\left.\mathrm{Po}_{\text {hid }}\right), \mathrm{H}_{2} \mathrm{SO}_{4}\left(\mathrm{P}_{\text {acid }}\right)$ and, finally, by digestion with $\mathrm{H}_{2} \mathrm{SO}_{4} / \mathrm{H}_{2} \mathrm{O}_{2}\left(\mathrm{P}_{\text {resd }}\right)$. Nine FYM samples were extracted with water, resin, Mehlich-1, $\mathrm{H}_{2} \mathrm{SO}_{4}, \mathrm{NaOH}$ or digestion with $\mathrm{H}_{2} \mathrm{SO}_{4} / \mathrm{H}_{2} \mathrm{O}_{2}$, not sequentially, and the extracts analyzed for $\mathrm{P}$. The sampled areas had homogeneous, sandy and $P$-deficient soils; increases in total soil $P\left(P_{t}\right)$ above the mean value of the control areas (up to $274 \mathrm{mg} \mathrm{kg}^{-1}$ in the 0-20 cm layer of the most P-enriched samples) were therefore attributed to FYM applications, which was the only external $P$ input in the region. Regression analysis was used to study the relationship between soil $P$ fractions and $P_{t}$. The $P_{\text {acid }}$ fraction, related to Ca-P forms, showed the greatest increases $(p<0.01)$ as a result of FYM applications, rising from $8.4 \mathrm{mg} \mathrm{kg}^{-1}$ in a non-fertilized sample to $43.8 \mathrm{mg} \mathrm{kg}^{-1}$ in the sample with the highest $P_{t}$ content. The sum of $P_{w}, P_{r e s}$ and $P i_{b i c}$, considered as labile $P$, showed comparable increases with $\mathrm{P}_{\text {acid }}$, while $\mathrm{Pi}_{\text {hid }}$ showed the smallest increase due to FYM applications. Organic $\mathrm{P}$ forms also increased, more so the fraction $\mathrm{Po}_{\text {hid }}$,

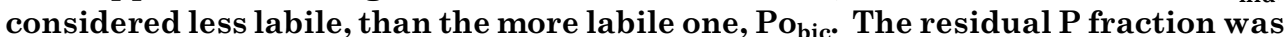
practically half of $P_{t}$, independently of the $P_{t}$ value. Increases in labile $P, P_{\text {acid }}$ and organic $P$ were justified by the high average concentration of $P_{w}(36 \%), P_{\text {acid }}(34 \%)$, and $\mathrm{Po}_{\text {hid }}(30 \%)$ in the FYM. Significant changes in the proportion of $P$ forms among soil layers indicated the downward movement of $P$ in organic forms.
\end{abstract}

Index terms: organic phosphorus, water soluble phosphorus, phosphorus leaching.

\footnotetext{
(1) Recebido para publicação em abril de 2008 e aprovado em janeiro de 2009.

(2) Pesquisador da Embrapa Meio-Norte. Av. Duque de Caxias 5650, Buenos Aires, CEP 64006-220 Teresina (PI). Bolsista DTI/ CNPq. E-mail: reginassg@uol.com.br

(3) Professor Titular da Universidade Federal de Pernambuco - DEN/UFPE. Av Prof. Luiz Freire 1000, CEP 50740-540 Recife (PE). E-mail: salcedo@ufpe.br
} 


\title{
RESUMO: FRAÇÕES DE FÓSFORO EM SOLOS ARENOSOS ADUBADOS COM ESTERCO POR LONGOS PERÍODOS
}

\begin{abstract}
Frações de P foram quantificadas em amostras de solo obtidas em áreas não adubadas e adubadas com esterco bovino e em amostras do esterco utilizado na região agreste do estado da Paraíba, Brasil. As amostras de solo foram coletadas nas camadas de 0-20, 20-40 e 40$60 \mathrm{~cm}$ em 18 áreas agrícolas que, pelos históricos levantados junto aos agricultores, vinham

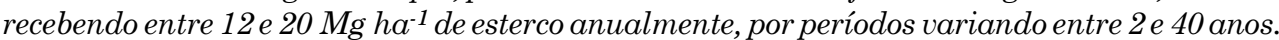
Como controle, foram retiradas amostras de solo em quatro áreas sob pastagem sem histórico de adubação. O P nas amostras de solo foi sequencialmente extraído com água $\left(P_{w}\right)$, resina $\left(\mathrm{P}_{\text {res }}\right), \mathrm{NaHCO}_{3}\left(\mathrm{Pi}_{\text {bic }}\right.$ e $\left.\mathrm{Po}_{\text {bic }}\right), \mathrm{NaOH}\left(\mathrm{Pi}_{\text {hid }}\right.$ e $\left.\mathrm{Po}_{\text {hid }}\right), \mathrm{H}_{2} \mathrm{SO}_{4}\left(\mathrm{P}_{\text {ácido }}\right)$ e, finalmente, por digestão com $\mathrm{H}_{2} \mathrm{SO}_{4} / \mathrm{H}_{2} \mathrm{O}_{2}\left(P_{\text {resd }}\right)$. Em nove amostras de esterco foi determinado o Pextraível por água, resina, Mehlich-1, $\mathrm{H}_{2} \mathrm{SO}_{4}, \mathrm{NaOH}$ e digestão com $\mathrm{H}_{2} \mathrm{SO}_{4} / \mathrm{H}_{2} \mathrm{O}_{2}$, não sequencialmente. As áreas amostradas apresentam solos homogêneos, arenosos e muito deficientes em $P$, de forma que a variação encontrada no teor de P total $\left(P_{t}\right)$, entre um mínimo de $50 \mathrm{mg} \mathrm{kg}^{-1} \mathrm{em}$ área controle e um máximo de $393 \mathrm{mg} \mathrm{kg}^{-1}$ em área adubada, foi atribuída às adições de esterco, único insumo externo de P na região. As concentrações de $P$ do solo nas frações foram analisadas por regressão em relação aos teores de $P$ total $\left(P_{t}\right)$. A fração $P_{\text {ácido, }}$ considerada como $P$ ligado ao $C a$, foi a que apresentou o maior aumento $(p<0,01)$ como resultado das adições de esterco, passando de 8,4 mg kg-1 em amostra não adubada para 43,8 $\mathrm{mg} \mathrm{kg}^{-1}$ na amostra com maior teor de $P_{t}$. A soma de $P_{w}$, $P_{\text {res }}$ e $P i_{b i c}$, considerada como $P$ lábil, apresentou acréscimos semelhantes à fração $P_{\text {ácido }}$, enquanto que, a fração $P i_{\text {hid }}$, mostrou o menor aumento em função da adição de esterco. As formas de Porgânico também aumentaram, sendo maiores ( $p<0,01)$ os aumentos da fração $P_{o_{h i d}}$, menos lábil, que os da fração $P_{o_{b i c}}$. O fósforo residual foi praticamente metade do $P_{t}$, em toda a faixa de variação deste último. Os acréscimos no $P$ lábil, $P_{\text {ácido }}$ e P orgânico foram justificados pelo elevado teor médio de P solúvel em água (36\%), de P ligado ao Ca (34\%) e de P em formas orgânicas (30\%) do esterco. Variações significativas nas proporções de Pentre as camadas de solo indicaram que, nas áreas adubadas, houve movimento descendente do Pem formas orgânicas.
\end{abstract}

Termos de indexação: fósforo orgânico, $P$ solúvel em água, lixiviação de $P$.

\section{INTRODUCTION}

In general, soils used in subsistence agriculture areas are $\mathrm{N}$ and $\mathrm{P}$-deficient and FYM is a widely used alternative to supply these nutrients in the semi-arid and rural regions of northeastern Brazil (Sabourin et al., 2000; Menezes et al., 2002; Menezes \& Salcedo, 2007; Silva et al., 2007). The use of FYM is not generalized for subsistence crops (maize, bean and cassava) and depends on the local availability and price, while for commercial crops such as potato, the application is annual and often complemented with mineral $N$ fertilizer (Sabourin et al., 2000).

The FYM rates applied in the semi-arid region are empirical and average $16 \mathrm{Mg} \mathrm{ha}{ }^{-1}$ annually, because there are no specific recommendations. In other countries FYM rates are based on $\mathrm{N}$ crop requirements (Akhtar et al., 2004). As the N/P ratio of manure is generally lower than the N/P ratio of plant uptake, applications exceed the crop needs, resulting in soil $\mathrm{P}$ accumulation $\mathrm{P}$ and potential loss. Data regarding this undesirable effect in low input family agriculture in the semi-arid region of Brazil have recently been published (Galvão et al., 2008; Menezes \& Oliveira, 2008). Data on P accumulation (Sharpley et al., 2004) and P losses through leaching (Koopmans et al., 2007) related to animal manure applications have also been reported in other countries (Siddique \& Robinson, 2004; Anderson \& Magdoff, 2005).

Most $\mathrm{P}$ in manures is in inorganic forms (Sharpley \& Moyer, 2000; Cassol et al., 2001; Eghball, 2002). Dou et al. (2000) found that approximately $70 \%$ of the $\mathrm{P}$ in cattle manure was water-extractable, but this type of information is not available for the FYM used in the semi-arid region of Brazil. There is no information either on the transformations of this $\mathrm{P}$ source after several years of FYM application to the soil. Data on the effects of animal residue application on soil $\mathrm{P}$ forms come mainly from countries where meat production is based on confined animals (e.g. poultry and pig production, ruminant feedlots) and where significant amounts of this type of residue are applied to crops in liquid (Hountin et al., 2000), semisolid (He \& Honeycutt, 2001) and solid form (Hao et al., 2008).

The sequential $\mathrm{P}$ extraction (Hedley et al., 1982) provided relevant information on the distribution of soil $\mathrm{P}$ in inorganic and organic pools. In this sequential extraction, the $\mathrm{P}$ forms initially extracted by resin and sodium bicarbonate are considered more labile; 
then, the fraction extracted by sodium hydroxide is considered moderately labile and includes $\mathrm{P}$ associated with $\mathrm{Al}$ and $\mathrm{Fe}$ oxides; next, the acid-extracted fraction is considered related to apatite and other $\mathrm{Ca}$ phosphates, which are less reactive; finally, $\mathrm{P}$ determined after a sulphuric-peroxide digestion represents mostly recalcitrant phosphate forms, probably also including organic $\mathrm{P}$ forms (Araújo et al., 1993, 2003). In general, studies with this method in manure-fertilized soils are restricted to the surface layer (Sharpley et al., 2004; Lehmann et al., 2005), while less information is available on the relative enrichment of $\mathrm{P}$ fractions in deeper layers (Sue et al., 2007).

The purpose of this study was to investigate the $\mathrm{P}$ increase and distribution in organic and inorganic fractions in the 0-20, 20-40, and 40-60 cm soil layers, resulting from FYM fertilization during periods of 2 to 40 years, in 22 areas with sandy soils used for family agriculture, four of which were not fertilized, in the municipality of Esperança-PB, as well as the $\mathrm{P}$ fractions in FYM samples used by the farmers.

\section{MATERIAL AND METHODS}

Twenty-two farms of family agriculture were chosen in the municipality of Esperança, in the semiarid of the state of Paraiba, Brazil. In small areas of these farms potato (Solanum tuberosum L.) is intercropped with anise (Pimpinella anisum L.), which are considered commercial crops in the region, in addition to traditional food crops (subsistence) such as corn (Zea mays L.), common bean (Phaseolus vulgaris L.), cowpea (Vigna unguiculata L.), cassava (Manihot esculenta Crantz) and broad bean (Vicia faba L.) (Sabourin et al., 2000). The dominant soil type in the sampling areas is a "Neossolo Regolítico eutrófico" according to the Brazilian Soil Classification System (Embrapa, 1999) or an eutrophic Usthortent, according to the US Soil Classification System. The texture is sandy to sandy-loam and the relief slightly hilly to hilly. The mean annual rainfall is $800 \mathrm{~mm}$ distributed from March to August, although the total rainfall and distribution can be very variable (Sabourin et al., 2000).

According to land use records based on interviews with landowners, on 18 of the 22 sampling areas potato had been intercropped with anise and manurefertilized, while four pasture areas had not been fertilized in the last 10 years. Of the fertilized areas, 14 had been fertilized between 15 and 40 years and four for less than six years. The annual application of composted FYM (15\% moisture content) varied between 12 and $20 \mathrm{Mg} \mathrm{ha}^{-1}$ (mean of $16 \mathrm{Mg} \mathrm{ha}^{-1}$ ), but one of the areas had received $28 \mathrm{Mg} \mathrm{ha}^{-1}$ in the two previous years before sampling. In most cases the FYM had been bought from external sources. In the areas cultivated with potato, 13 of the 18 farmers applied commercial $\mathrm{N}$ fertilizer (urea or ammonium sulphate) at $\mathrm{N}$ rates between 32 and $67 \mathrm{~kg} \mathrm{ha}^{-1}$ (mean of $55 \mathrm{~kg} \mathrm{ha}^{-1}$ ). The organic and mineral fertilizers were applied at potato planting, although depending on the beginning of the rainy period, this crop is normally preceded by bean.

In the areas with potato - anise intercropping (normally 5 rows of potato for one row of anise), simple soil samples were collected from the 0-20, 20-40 and 40-60 cm layers, in ten potato rows (each row at the center of the intercropping sequence). The simple samples were air-dried and sieved (2 $\mathrm{mm}$ mesh). Equal quantities of weighed soil from each simple sample were mixed and homogenized to form a bulk sample for physical and chemical analyses. A characterization of these bulked samples was published by Galvão et al. (2008). Summarizing, samples from the control areas $(0-20 \mathrm{~cm})$ contained 839, 112 and $49 \mathrm{~g} \mathrm{~kg}^{-1}$ sand, silt and clay, respectively, $\mathrm{pH}\left(\mathrm{H}_{2} \mathrm{O}\right), 5.5 ; 3.9 \mathrm{~g} \mathrm{~kg}^{-1}$ of total organic C (TOC), $86 \mathrm{mg} \mathrm{kg}^{-1}$ of total P, $3.8 \mathrm{mg} \mathrm{kg}^{-1}$ and $63 \mathrm{mg} \mathrm{kg}^{-1}$ of Mehlich-1 extractable $\mathrm{P}$ and $\mathrm{K}$, respectively, and 0.55 and $0.18 \mathrm{cmol}_{\mathrm{c}} \mathrm{kg}^{-1}$ of $\mathrm{Ca}$ and $\mathrm{Mg}$, respectively. In the 40-60 $\mathrm{cm}$ layer, the extracted $\mathrm{P}$ and $\mathrm{K}$ decreased to 1.1 and $3.6 \mathrm{mg} \mathrm{kg}^{-1}$, and Ca to $0.36 \mathrm{cmol}_{\mathrm{c}} \mathrm{kg}^{-1}$, while the other attributes remained almost unchanged, compared to the surface layer.

The $\mathrm{P}$ fractions in the bulk soil samples were sequentially extracted using the Hedley et al. (1982) procedure, modified by Araújo et al. (1993). This method separates soil P into five inorganic, two organic and one residual fraction. Subsamples of $1.0 \mathrm{~g}$ of soil passed through a $0.25 \mathrm{~mm}$ sieve were weighed in $50 \mathrm{~mL}$ centrifuge tubes and after addition of $30 \mathrm{~mL}$ of extractant shaken for $16 \mathrm{~h}$ in a wrist-action shaker. The inorganic $\mathrm{P}$ fractions were sequentially determined in the following order: (1) Pi-water $\left(\mathrm{P}_{\mathrm{w}}\right)$, extracted in $30 \mathrm{~mL}$ of deionized water and quantified by the malachite green method (Ohno \& Zibilski, 1991); (2) Pi-resin $\left(\mathrm{P}_{\text {res }}\right)$, extracted with anionic exchange resin beads in nylon bags ("resin bag") and $30 \mathrm{~mL}$ of deionized water. After shaking, the resin-adsorbed $\mathrm{P}$ was eluted with $0.5 \mathrm{~mol} \mathrm{~L}-1 \mathrm{HCl}$; (3) $\mathrm{Pi}-\mathrm{NaHCO}_{3}\left(\mathrm{Pi}_{\text {bic }}\right)$, extracted with $30 \mathrm{~mL}$ of $0.5 \mathrm{~mol} \mathrm{~L}^{-1} \mathrm{NaHCO}_{3}, \mathrm{pH} 8.5$; (4) $\mathrm{Pi}-\mathrm{NaOH}\left(\mathrm{Pi}_{\text {hid }}\right)$, extracted with $30 \mathrm{~mL}$ of $0.1 \mathrm{~mol} \mathrm{~L}^{-1} \mathrm{NaOH}$ and (5) $\mathrm{Pi}_{-} \mathrm{H}_{2} \mathrm{SO}_{4}\left(\mathrm{P}_{\text {acid }}\right)$, extracted with $30 \mathrm{~mL}$ of $1.0 \mathrm{~mol} \mathrm{~L}^{-1} \mathrm{H}_{2} \mathrm{SO}_{4}$. The inorganic $\mathrm{P}$ extracted with $\mathrm{NaHCO}_{3}$ and $\mathrm{NaOH}$ was determined in the supernatant, after acidification and centrifugation of the solid phase. An additional aliquot was taken from the $\mathrm{NaHCO}_{3}$ and $\mathrm{NaOH}$ extracts (extracts 3 and 4 ) to determine the total $\mathrm{P}$ concentration in the extract as well, digesting it with $1 \mathrm{~mL}$ of $24 \mathrm{~mol} \mathrm{~L}^{-1} \mathrm{H}_{2} \mathrm{SO}_{4}$ and $0.2 \mathrm{~g}$ of $\mathrm{K}_{2} \mathrm{~S}_{2} \mathrm{O}_{8}$, and autoclaving it for $1 \mathrm{~h}$ at $127^{\circ} \mathrm{C}$. Organic phosphorus was calculated as the difference between the total $\mathrm{P}$ and inorganic $\mathrm{P}$ concentration in each extract. These organic fractions, $\mathrm{Po}_{\text {bic }}$ and $\mathrm{Po}_{\text {hid }}$ were denominated according to the extracting solution. The soil residue remaining after the last acid extraction was digested 
with $\mathrm{H}_{2} \mathrm{SO}_{4} / \mathrm{H}_{2} \mathrm{O}_{2}$ at $360^{\circ} \mathrm{C}$ to determine the residual $\mathrm{P}$ fraction $\left(\mathrm{P}_{\text {resd }}\right)$. With the exception of waterextractable $\mathrm{P}$, all other $\mathrm{P}$ measurements were performed by the colorimetric method of Murphy \& Riley (1962), after $\mathrm{pH}$ adjustment using p-nitrophenol as indicator. Total soil $\mathrm{P}\left(\mathrm{P}_{\mathrm{t}}\right)$ was calculated as the sum of all fractions.

The FYM used in the cited region is very heterogeneous and Galvão et al. (2008) determined some of its properties. Further description of $\mathrm{P}$ in this material was sought to justify the variations in the $\mathrm{P}$ fractions of the soil; however, due to various methodological difficulties, it was not possible to adapt the sequential extraction used for the soil samples to the manure samples. Instead, independent extractions with water, resin, Mehlich-1, $\mathrm{H}_{2} \mathrm{SO}_{4} 1.0 \mathrm{~mol} \mathrm{~L}^{-1}$ and $\mathrm{NaOH} 0.1 \mathrm{~mol} \mathrm{~L}^{-1}$ were used (in this latter extract Pi and Po were determined as described above). Phosphorus in the extracts was quantified by the colorimetric method of Murphy \& Riley (1962).

Soils in the study region are relatively homogeneous, with predominance of the sand fraction and $\mathrm{P}_{\mathrm{t}}$ concentrations $<110 \mathrm{mg} \mathrm{kg}^{-1}$ when not fertilized. Higher $\mathrm{P}_{\mathrm{t}}$ concentrations in fertilized than in control areas were therefore attributed to FYM inputs. The absence of detailed management records did not allow a case-by-case study where rates and periods of FYM applications could be related with the current soil $\mathrm{P}_{\mathrm{t}}$ concentrations. For this reason, soil samples from all areas and soil layers were considered together for the analysis, by linear regression, of the relationship between $P_{t}$, an independent continuous variable, and $\mathrm{P}$ in each fraction or fraction combination as dependent variable. The equality of regression coefficients between fractions of interest was tested by orthogonal contrasts (Schabenberger \& Pierce, 2002).

To synthesize the data presentation separately for each fraction and layer, the areas were not considered individually, but grouped in four categories, using the $\mathrm{P}_{\mathrm{t}}$ concentration in the $0-20 \mathrm{~cm}$ layer as a grouping factor, thus transforming $\mathrm{P}_{t}$ in a classification variable. Group 1 included the four unfertilized soil samples ( $£ 110 \mathrm{mg} \mathrm{kg}^{-1}$ ), while samples from fertilized areas were distributed in group $2\left(111-220 \mathrm{mg} \mathrm{kg}^{-1}\right.$, $\mathrm{n}=09)$, group $3\left(221-330 \mathrm{mg} \mathrm{kg}^{-1}, \mathrm{n}=05\right)$ or group 4 (331-440 mg kg-1, $\mathrm{n}=04$ ). Independently of their $\mathrm{P}_{t}$ concentrations, samples from the $20-40$ and $40-60 \mathrm{~cm}$ layers were included in the same group of their corresponding 0-20 cm sample, maintaining the three samples that comprised the $0-60 \mathrm{~cm}$ layer of each area in only one group. In this analysis, $\mathrm{P}$ in each fraction was expressed as the percentage of total $\mathrm{P}$ content. Since variations in $\mathrm{P}$ content among soil layers are not independent, due to the lack of randomization and autocorrelation of $\mathrm{P}$ contents among them, a mixed statistical linear model was used that estimates an additional experimental error term in the analysis of variance, to compensate for these specific experimental conditions (Schabenberger \& Pierce, 2002; R DEVELOPMENT..., 2008). The percentages of $\mathrm{P}$ in the fractions between layers were compared by orthogonal contrasts $(0-20$ versus $20-40$ and $20-40$ versus $40-60 \mathrm{~cm}$ ).

\section{RESULTS AND DISCUSSION}

The $\mathrm{P}$ concentrations in the three labile fractions, $\mathrm{P}_{\mathrm{w}}, \mathrm{P}_{\text {res }}$ and $\mathrm{P}_{\mathrm{bic}}$ increased significantly $(\mathrm{p}<0.01)$ with the increase in $\mathrm{P}_{\mathrm{t}}$ in the soil, considering the samples of the three layers together (Figure 1a). The increase in soil labile $\mathrm{P}$ concentrations can be justified by the high $\mathrm{P}_{\mathrm{w}}$ and $\mathrm{P}_{\text {res }}$ concentrations in the FYM samples $\left(\mathrm{P}_{\mathrm{w}}=1.0\right.$ and $\left.\mathrm{P}_{\text {res }}=1.2 \mathrm{~g} \mathrm{~kg}^{-1} \mathrm{MS}\right)$ that represent approximately $36 \%$ of the $\mathrm{P}_{\mathrm{t}}$ contained in this material (Table 1). It is worth remembering that as the $\mathrm{P}$ extraction from the FYM was not sequential, unlike the soil samples, practically all resin extractable $\mathrm{P}$ was the water-soluble $\mathrm{P}$. The mean $\mathrm{Pw}$ values found by Sharpley \& Moyer (2000) in FYM were within the 15-47\% range of $\mathrm{P}_{t}$, while Cassol et al. (2001) reached an extraction of $65 \%$ of $\mathrm{P}_{t}$ with resin and Ajiboye et al. (2004) $40 \%$ of $\mathrm{P}_{\mathrm{t}}$ with water.

In the comparative analysis of the three regression coefficients, the $\mathrm{P}_{\text {res }}$ increase rate was higher $(p<0.01)$ than that of the other two fractions, which were equal. This rate was practically $0.1 \mathrm{mg}$ of $\mathrm{P}_{\text {res }}$ for each $\mathrm{mg}$ of increase in $\mathrm{P}_{t}$, that is, $10 \%$ of the $\mathrm{P}$ added via FYM was resin-extractable, independently of the $P_{t}$ level. This was unexpected, since, in the soil samples, $\mathrm{P}_{\text {res }}$ did not include the $\mathrm{P}_{\mathrm{w}}$ concentration, and these soils are dominated by the sand fraction (Galvão et al., 2008), with low values of labile $\mathrm{P}$ in the solid phase. In the case of $\mathrm{P}_{\mathrm{w}}$ and $\mathrm{P}_{\text {bic }}$ this rate of increase was approximately $5 \%$. Water-soluble $\mathrm{P}$ was not included in the sequential extraction proposed by Hedley et al. (1982) and is rarely determined in soil analysis because the very low concentrations cause methodological difficulties; the fraction is however frequently determined in studies related with the use of FYM (Kleinman et al., 2005).

The $\mathrm{P}_{\mathrm{w}}$ contents in nine soil samples were highly overestimated by the corresponding regression equation, particularly those with $\mathrm{P}_{\mathrm{t}}$ contents above $200 \mathrm{mg} \mathrm{kg}^{-1}$ (Figure 1a). The $\mathrm{Fe}_{\text {ox }}$ and $\mathrm{Fe}_{\mathrm{DCB}}$ concentrations in these samples were also higher than in the others, oscillating between 3 and $7 \mathrm{~g} \mathrm{~kg}^{-1}$ (data not shown) and probably limited $\mathrm{P}$ concentrations to low levels in the soil solution by means of sorption mechanisms (Novais \& Smyth, 1999); conversely, the $\mathrm{P}_{\mathrm{w}}$ concentrations in samples with extractable $\mathrm{Fe}<$ $3 \mathrm{~g} \mathrm{~kg}^{-1}$ were better adjusted by the regression equation. These results suggest the usefulness of determining the $\mathrm{Fe}$ content in manure-fertilized sandy soils, to diagnose the loss potential of watersoluble P. 
Table 1. Mean, minimum, maximum and standard deviation statistics for total $\mathrm{P}$, Mehlich-1, resin, water, $1 \mathrm{~mol} \mathrm{~L}^{-1} \mathrm{H}_{2} \mathrm{SO}_{4}$ and $0,1 \mathrm{~mol} \mathrm{~L}^{-1} \mathrm{NaOH}$ extractable $\mathrm{P}$, and total Ca and Fe, in FYM dry matter samples (n = 9) from nine farms in Esperança county, PB

\begin{tabular}{|c|c|c|c|c|}
\hline Element & Mean & Minimum & Maximum & Std. deviation \\
\hline & \multicolumn{4}{|c|}{$-\mathrm{g} \mathrm{kg}^{-1}$} \\
\hline Total P & 2.95 & 1.50 & 6.24 & 1.67 \\
\hline Mehlich-1 P & 2.31 & 1.06 & 5.19 & 1.42 \\
\hline Resin P & 1.05 & 0.53 & 1.89 & 0.47 \\
\hline Water P & 1.05 & 0.19 & 2.69 & 0.84 \\
\hline $\mathrm{H}_{2} \mathrm{SO}_{4} 0.1 \mathrm{~mol} \mathrm{~L}^{-1} \mathrm{P}$ & 2.10 & 1.00 & 4.25 & 1.11 \\
\hline $\mathrm{NaOH} 0.1 \mathrm{~mol} \mathrm{~L}^{-1} \mathrm{Pi}$ & 0.39 & 0.11 & 1.19 & 0.35 \\
\hline $\mathrm{NaOH} 0.1 \mathrm{~mol} \mathrm{~L}^{-1} \mathrm{Po}$ & 1.02 & 0.55 & 1.70 & 0.47 \\
\hline Total $\mathrm{Ca}$ & 14.0 & 6.20 & 25.5 & 6.34 \\
\hline Total Fe & 2.22 & 0.69 & 5.86 & 1.32 \\
\hline
\end{tabular}

The sum of $\mathrm{P}$ concentrations in the three fractions that constitute the labile $\mathrm{P}\left(\mathrm{P}_{\mathrm{w}}+\mathrm{P}_{\text {res }}+\mathrm{Pi}_{\text {bic }}\right)$ was compared with the content of $\mathrm{P}$ extractable by $\mathrm{NaOH}$ $\left(\mathrm{Pi}_{\text {hid }}\right)$ and by acid $\left(\mathrm{P}_{\text {acid }}\right)$ considering all samples (Figure 1b). The rate of increase of the labile Pi fraction was similar to $\mathrm{P}_{\text {acid }}$ and both were higher $(\mathrm{p}<0.01)$ than that of $\mathrm{Pi}_{\text {hid }}$. However, when considering the $\mathrm{P}_{\mathrm{w}}, \mathrm{P}_{\text {res }}$ and $\mathrm{Pi}_{\text {bic }}$ fractions separately, $\mathrm{P}_{\text {acid }}$ was the inorganic fraction with the highest increases, when considering the data from the three layers together.

The increase in $\mathrm{P}_{\text {acid }}$ concentration ( $\mathrm{P}$ associated to $\mathrm{Ca}$ ) is consistent with the chemical FYM composition, since, on average, almost $70 \%$ of the total $\mathrm{P}$ was extracted by the two acid solutions tested (Table 1). Deducting the water-soluble P from acidextractable P , $34 \%$ of the P in the FYM appeared to be associated with $\mathrm{Ca}$, which would then be the second most abundant fraction in the manure. This association is justified by the high mean $\mathrm{Ca}$ concentration, $14 \mathrm{~g} \mathrm{~kg}^{-1}$, in dry FYM (Table 1); in fact, FYM applications in the most fertilized soils elevated the total Ca content almost 10-fold over the unfertilized soils (in Figure $2 \mathrm{a}$ the $\mathrm{P}_{\mathrm{t}}$ values in unfertilized samples are $<90 \mathrm{mg} \mathrm{kg}^{-1}$ ). The increases would have been even higher if it were not for the quadratic effect of the data (Figure 2a), probably caused by the higher leaching of Ca than of P (Galvão et al., 2008).

In addition to the relationship with $\mathrm{P}_{\mathrm{t}}$, the total soil Ca was also closely related with the $\mathrm{P}_{\text {acid }}$ fraction (Figure 2b). FYM applications contributed to increases in soil pH (Galvão et al., 2008), which favor the solubilization of $\mathrm{Fe}$ and $\mathrm{Al}$ phosphates, while $\mathrm{Ca}$ applications promote precipitation of Ca phosphates (Lindsay, 1979). Commonly, in highly weathered soils, typical of the humid tropical region in northeastern Brazil (Ball-Coelho et al., 1993; Araújo et al, 1993) or in the semi-arid region when originated from weathered sedimentary rocks (Tiessen et al., 1992; Araújo et al., 2004), the Al-P and Fe-P forms,

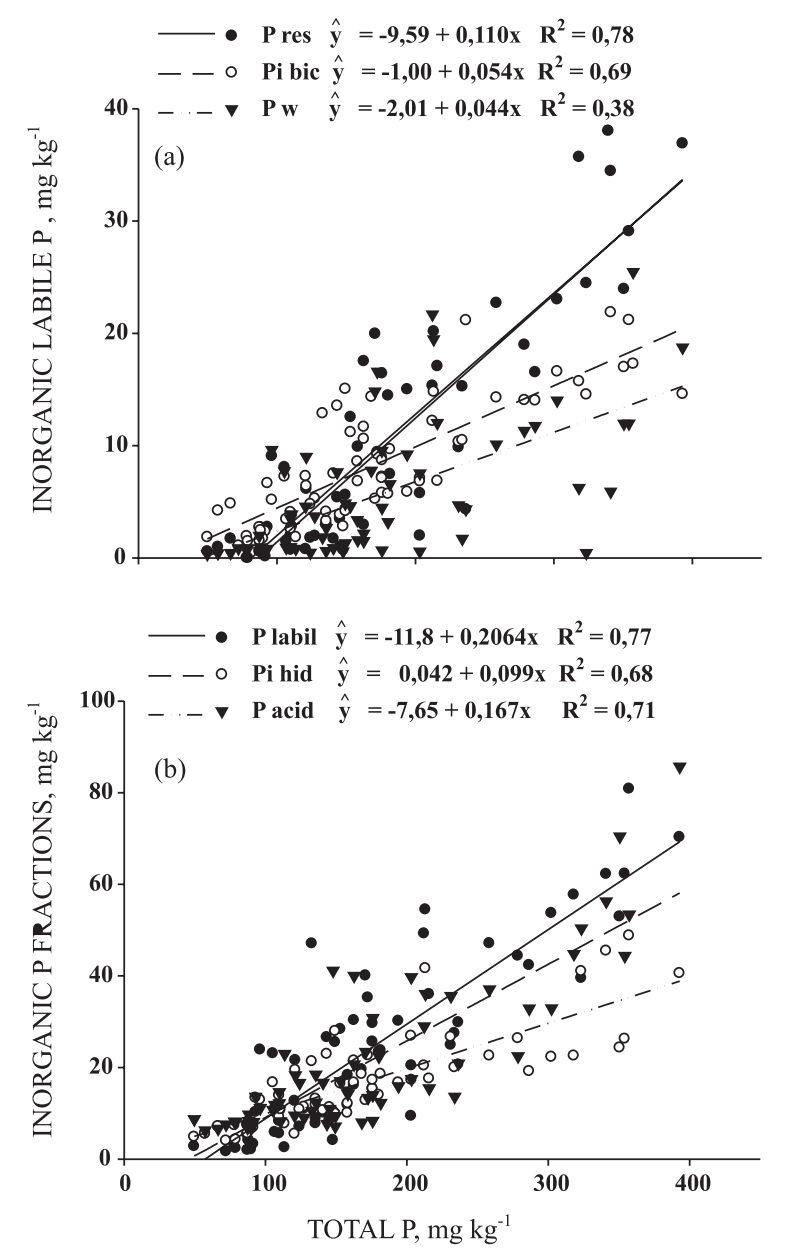

Figure 1. Relationship between the concentrations of labile inorganic $P$ fractions and $P_{t}(a)$ and between inorganic $P$ fractions and $P_{t}(b)$, in soil samples taken from three depths in areas fertilized or not with FYM $(n=66)$.

extracted by $\mathrm{NaOH}$, are proportionally higher than Ca-P forms (Salcedo, 2007). The opposite situation 
was observed in soils derived from crystalline materials in the semi-arid region, in which the Caassociated fraction predominates (Silveira, 2000). In this study, the proportions of $\mathrm{Pi}_{\text {hid }}$ and $\mathrm{P}_{\text {acid }}$ were very similar for $\mathrm{P}_{\mathrm{t}}$ concentrations $\leq 100 \mathrm{mg} \mathrm{kg}^{-1}$ (unfertilized samples, Figure 1b), but continuous FYM fertilization modified this situation; Ca-associated forms became predominant $\left(\mathrm{P}_{\text {acid }}\right)$, instead of $\mathrm{Fe}$ or $\mathrm{Al}$ $\left(\mathrm{P}_{\text {hid }}\right)$ (Figure 1b). This is consistent with the lower $\mathrm{P}$ quantity in the FYM associated to Fe, extracted by $\mathrm{NaOH}$ (12\% of total P, Table 1). Graetz \& Nair (1995) studied soils under long-term FYM fertilization and observed that non-manured areas contained $44 \%$ of $\mathrm{Fe}$ and $\mathrm{Al}-\mathrm{P}$ and only $9 \%$ of $\mathrm{Ca}-\mathrm{P}$, whereas the manured areas contained $8 \%$ of $\mathrm{Fe}-$ and $\mathrm{Al}-\mathrm{P}$ and $70 \%$ of Ca-P.

Regarding the organic $\mathrm{P}$ forms, both fractions increased $(p<0.01)$ with the increase in $P_{t}$, but the $\mathrm{Po}_{\text {hid }}$ fraction increased at a greater rate $(\mathrm{p}<0.01)$ than $\mathrm{Po}_{\text {bic }}$ (Figure 3a). These tendencies agree with
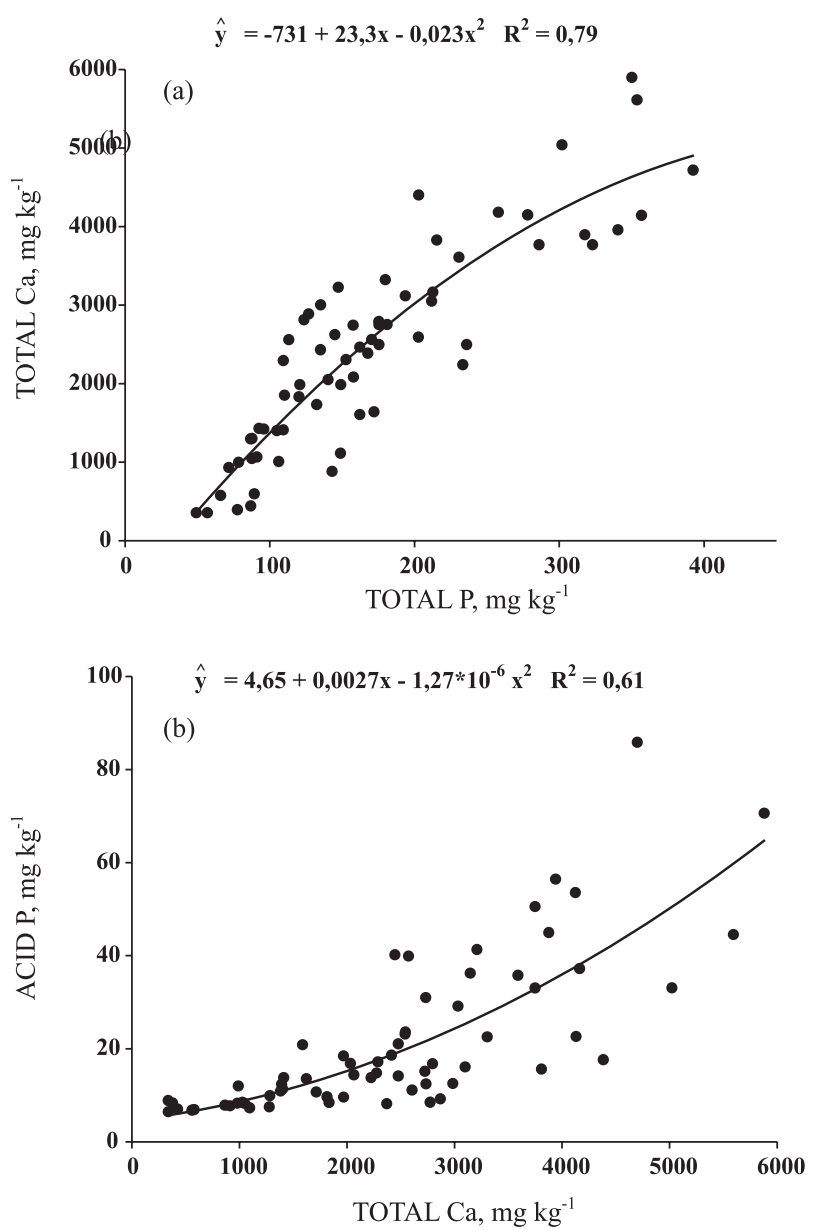

Figure 2. Relationship between total $\mathrm{Ca}$ and $\mathbf{P}_{t}$ concentrations (a) and between acid extractable $\mathrm{P}$ and total $\mathrm{Ca}(\mathrm{b})$, in soil samples taken from three depths in areas fertilized or not with FYM $(\mathrm{n}=66)$. the lability attributed to $\mathrm{P}$ in these fractions, where $\mathrm{NaOH}$ is relatively less labile and tends to accumulate in the soil, while the relatively more labile bicarbonate maintains low concentrations in spite of increases in $\mathrm{P}_{\mathrm{t}}$ (Araújo et al., 1993; Silveira et al., 2006). These results are also consistent with the chemical composition of the FYM, which contained $1.02 \mathrm{~g} \mathrm{~kg}^{-1}$ of $\mathrm{Po}_{\text {hid }}$, corresponding to $32 \%$ of total P (Table 1). In fractioned samples of cattle and poultry droppings, Cassol et al. (2001) determined total Po values between 0.81 and $2.72 \mathrm{~g} \mathrm{~kg}^{-1}$ or 16 and $25 \%$ of $\mathrm{P}_{\mathrm{t}}$, respectively. The $\mathrm{P}$ in the FYM analyzed in this study was approximately two-thirds in the mineral and one-third in the organic form; the predominance of inorganic forms results from the phosphatase activity induced by microorganisms in the rumen which, in acid medium, will hydrolyze the organic phosphates (Cassol et al., 2001). Other studies have shown the preferential entry of inorganic rather than organic $P$ forms into the soil, after long-term application of different manure types (Sharpley et al., 2004; Akhtar et al., 2004). The higher proportion of Po in the manure samples of this study than in that of Cassol et al. (2001) probably arises from the different systems of extraction used (not sequential in the present case) as well as from probable differences in the animals' diet, which affects the manure composition.

Regression functions (Figure $3 b$ ) summarize the $\mathrm{P}$ partitioning among inorganic $\left(\mathrm{P}_{\mathrm{w}}+\mathrm{P}_{\text {res }}+\mathrm{Pi}_{\text {bic }}+\right.$ $\left.\mathrm{Pi}_{\text {hid }}+\mathrm{P}_{\text {ácido }}\right)$, organic $\left(\mathrm{Po}_{\text {bic }}+\mathrm{Po}_{\text {hid }}\right)$ and residual pools, due to $\mathrm{P}_{\mathrm{t}}$ increases resulting from FYM applications. The rate of increase of $\mathrm{P}_{\text {resd }}$ and of the sum of $\mathrm{Pi}$ fractions was more pronounced than the sum of $\mathrm{Po}$, while the distribution between the sum of $\mathrm{Pi}$ and $\mathrm{P}_{\text {resd }}$ was relatively constant (Figure $3 b$ ). However, it should be noticed that part of the $\mathrm{P}_{\text {resd }}$ contains organic $\mathrm{P}$ forms as well (Araújo et al., 1993), which can partially change the proportions observed in Figure $3 \mathrm{~b}$, although probably without altering the prevalence of $\mathrm{Pi}$ forms. It is also worth noting the curved nature of the function of the $\mathrm{P}_{\text {resd }}$ fraction, which suggests an inversion in the predominance of the sum of $\mathrm{Pi}$ and $\mathrm{P}_{\text {resd }}$ if the observed trend is maintained as the $P_{t}$ content increases.

Statistical analysis of the changes in the $P$ fractions due to the two sources of variation, namely, three soil layers and four $\mathrm{P}_{t}$ groups (the first $\mathrm{P}_{t}$ group consisting of the unfertilized areas (Table 2) showed no significant interactions for any of the $\mathrm{P}$ fractions; the contrasts between layers were therefore established for the main effect of the variable depth (Table 3). For the inorganic fractions, accumulations were only observed for $P_{w}$ $(p<0.01)$ in one layer compared to the one below. Significant accumulations were also observed in both organic $\mathrm{P}$ fractions, $\mathrm{Po}_{\text {bic }}$ and $\mathrm{Po}_{\text {hid }}(\mathrm{p}<0.01)$, but in the opposite direction of $\mathrm{P}_{\mathrm{w}}$. The negative signal of the contrasts indicated preferential increases in the $20-40 \mathrm{~cm}$ in relation to the surface layer and in the $40-60 \mathrm{~cm}$ in relation to the $20-40 \mathrm{~cm}$ layer, indicating a downward movement of $\mathrm{P}$ in organic forms, a trend 
also observed by Djodjic et al. (2004). Except for $\mathrm{P}_{\mathrm{w}}$, the Pi fractions remained unaltered or decreased with depth, without significant changes in their relative positions $(\mathrm{p}<0.01)$ due to increases in the $\mathrm{P}_{\mathrm{t}}$ content (Table 2).

The observed increases of $\mathrm{P}_{t}$ concentrations in samples from different FYM-fertilized areas clearly demonstrate excessive applications of this nutrient source, which affected some soil chemical properties (Galvão et al., 2008) and possibly the control mechanism of solution $\mathrm{P}$. There was an excessive supply of water-soluble P, part of which was probably leached at the beginning of the rainy period, when there is little vegetation cover. In relation to the nonsoluble forms, excessive manuring changed the soil from a system with relatively similar amounts of $\mathrm{P}$ $(\mathrm{Fe}+\mathrm{Al})$ and $\mathrm{P}-\mathrm{Ca}$ forms to a system where $\mathrm{Ca}$ predominates; there is no information available on how this affects $\mathrm{P}$ availability to plants. Araújo et al. (1993) and Araújo et al. (2003) verified that all P fractions were plant-available, including the residual fraction, although with different relative intensities.
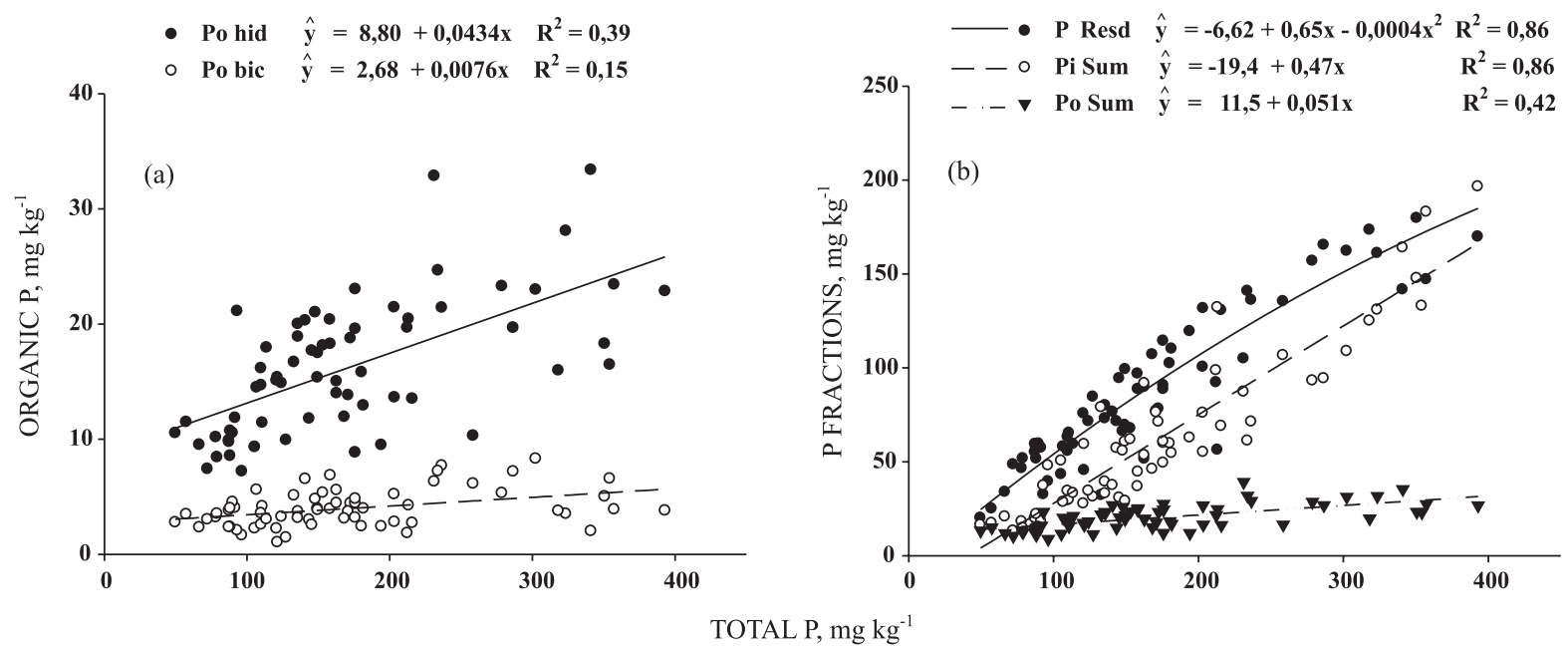

Figure 3. Relationship between $P$ concentration in organic fractions and $P_{t}(a)$ and between the residual fraction, the sum of inorganic fractions and the sum of organic fractions, and $P_{t}(b)$, in soil samples taken from three depths in areas fertilized or not with FYM $(n=66)$.

Table 2. Average proportion of $P$ fractions in soil samples allocated to four groups, according to the $P_{t}$ concentration in the $0-20 \mathrm{~cm}$ layer

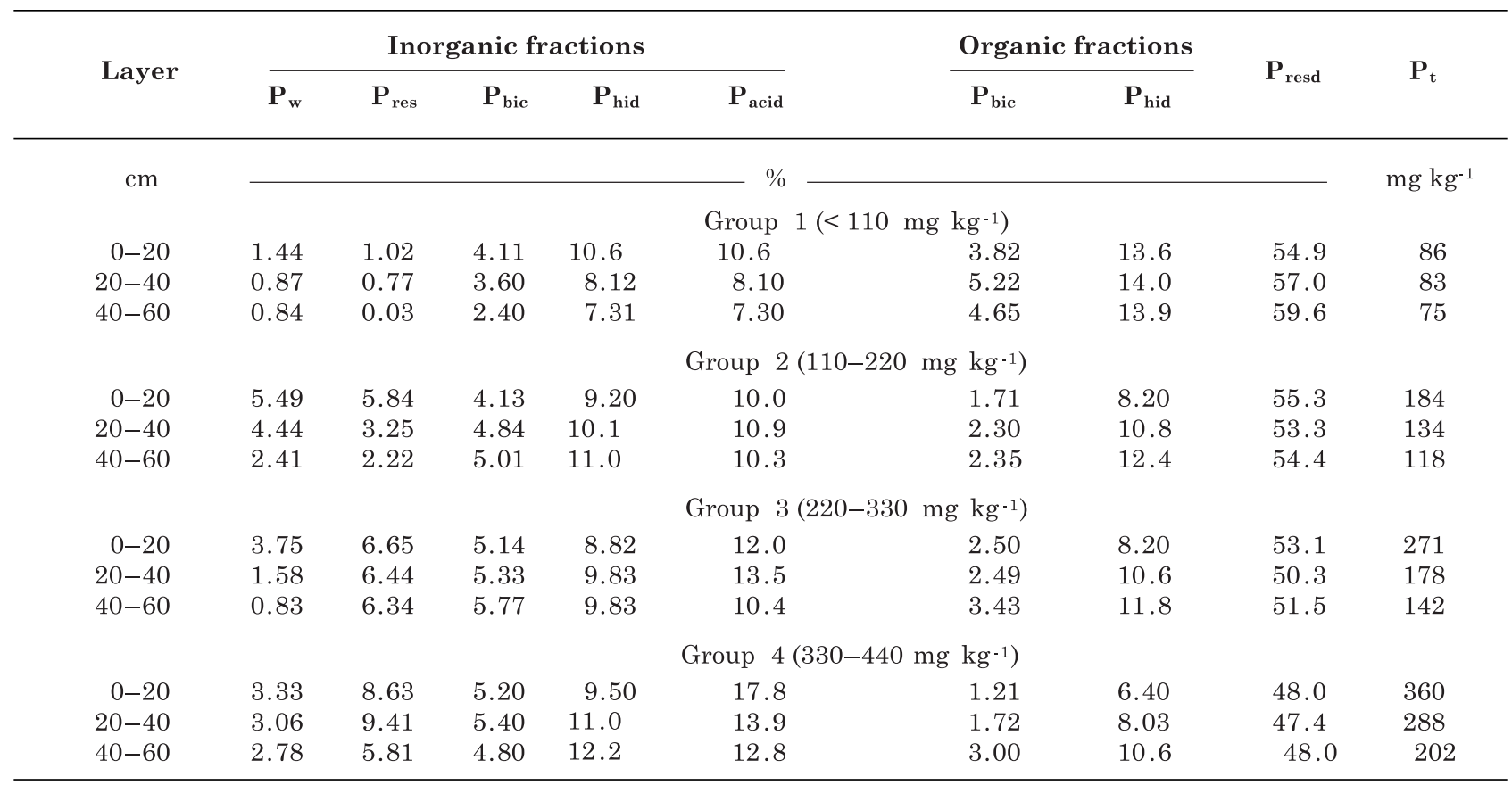


Table 3. Estimates of the orthogonal contrasts for the percentage of $P$ in each fraction relative to $P_{t}$, obtained in the comparison between two contiguous soil layers

\begin{tabular}{|c|c|c|c|c|c|c|c|c|}
\hline \multirow{2}{*}{ Contrast estimate } & \multicolumn{5}{|c|}{ Inorganic fraction } & \multicolumn{2}{|c|}{ Organic fraction } & \multirow{2}{*}{$\mathbf{P}_{\text {resd }}$} \\
\hline & $\mathbf{P}_{\mathrm{w}}$ & $\mathbf{P}_{\text {res }}$ & $\mathbf{P}_{\text {bic }}$ & $\mathbf{P}_{\text {hid }}$ & $\mathbf{P}_{\text {acid }}$ & $\mathbf{P}_{\text {bic }}$ & $\mathbf{P}_{\text {hid }}$ & \\
\hline & & & & - & 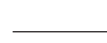 & & & 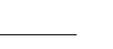 \\
\hline $0-20$ vs $20-40 \mathrm{~cm}$ & $1.02^{* * *}$ & $0.60^{\mathrm{ns}}$ & $-0.17 \mathrm{~ns}$ & $-0.25^{\mathrm{ns}}$ & $0.54^{\mathrm{ns}}$ & $-0.62^{* * *}$ & $-1.77^{* *}$ & $0.70^{\mathrm{ns}}$ \\
\hline $20-40$ vs $40-60 \mathrm{~cm}$ & $0.77^{* *}$ & $1.35^{\mathrm{ns}}$ & $0.29^{\mathrm{ns}}$ & $-0.34^{\mathrm{ns}}$ & $0.88^{\mathrm{ns}}$ & $-0.43^{* *}$ & $-1.31^{*}$ & $-1.24^{\mathrm{ns}}$ \\
\hline
\end{tabular}

***,**,* e ns: significant at the 1,5 and $10 \%$ level and non-significant, respectively.

The relative constancy of $\mathrm{P}_{\text {resd }}$ as a large proportion of $\mathrm{P}_{t}(50-60 \%)$, independently of the $\mathrm{P}_{t}$ content of the samples, indicates the need for improvement of the $P$ fractionation method. Moreover, the accumulation of all $\mathrm{P}$ forms demonstrates that, in view of the regionally limited availability, a more efficient management of FYM should be proposed. It would seem more reasonable to calculate the rates based on $\mathrm{P}$ demand rather than on $\mathrm{N}$ requirement of crops, considering the FYM as a good source of soluble $\mathrm{P}$ and $\mathrm{Ca}-\mathrm{P}$,. The synchronism between $\mathrm{N}$ supply and $\mathrm{N}$ corn requirements was not adequate when FYM was the source (Menezes \& Salcedo, 2007), which is probably the reason why farmers complement FYM with Nfertilizer for potato production (Galvão et al., 2008). By changing to a P-based demand, FYM rates could be significantly reduced, without affecting yields.

\section{CONCLUSIONS}

1. Long-term FYM applications resulted in an accumulation of soil $\mathrm{P}$, with prevalence of inorganic over organic forms.

2. With the increase in $\mathrm{P}_{\mathrm{t}}$ concentrations, accumulation rates were highest for the sum of the labile fractions $\left(\mathrm{P}_{\mathrm{w}}+\mathrm{P}_{\text {res }}+\mathrm{P}_{\text {bic }}\right)$ followed by the acidextractable fraction, related to $\mathrm{Ca}-\mathrm{P}$.

3. Continuous manure application to the soil caused $\mathrm{P}$ migration in organic form, from the $0-20$ to the 40-60 cm layer.

4. The FYM samples analyzed contained, on average, one third of water-soluble, one third of $\mathrm{Ca}$ associated and approximately one third of organic $\mathrm{P}$ forms.

\section{ACKNOWLEDGEMENTS}

The authors thank the technical staff of the Soil Fertility Laboratory, Department of Nuclear Energy/
Universidade Federal de Pernambuco (UFPE), for their help with the analytical work, they thank the farmers who contributed with samples, and are indebted to the Inter American Institute for Global Change (IAI) and National Council of Scientific and Technological Development (CNPq) for the financial support.

\section{LITERATURE CITED}

AKHTAR, M.; McCALLISTER, D.L.; FRANCIS, D.D. \& SCHEPERS, J.S. Manure source effects on soil phosphorus fractions and their distribution. Soil Sci., 170:183-190, 2004

AJIBOYE, B.; AKINREMI, O.O. \& RAEZ, G.J. Laboratory characterization of phosphorus in fresh and oven-dried organic amendments. J. Environ. Qual., 33:1062-1069, 2004.

ANDERSON, B.H. \& MAGDOFF, F.R. Relative movement and soil fixation of soluble organic and inorganic phosphorus. J. Environ. Qual., 34:2228-2233, 2005.

ARAÚJO, M.S.B.; SALCEDO, I.H. \& SAMPAIO, E.V.S.B. Efeito de fertilizações fosfatadas anuais em solos cultivados com cana-de-açúcar. II. Formas disponíveis e efeito residual do P acumulado. R. Bras. Ci. Solo, 17:397-403, 1993.

ARAÚJO, M.S.B.; SCHAEFER, C.E.R. \& SAMPAIO, E.V.S.B. Plant phosphorus availability in Latosols and Luvisols from northeastern semi-arid Brazil. Comm. Soil Sci. Plant Anal., 34:407-425, 2003.

ARAÚJO, M.S.B.; SCHAEFER, C.E.R. \& SAMPAIO, E.V.S.B. Frações de fósforo após extrações sucessivas com resina e incubação, em Latossolos e Luvissolos do semi-árido de Pernambuco. R. Bras. Ci. Solo, 28:259-268, 2004.

BALL-COELHO, B.; SALCEDO, I.H.; TIESSEN, H. \& STEWART, W.B. Short- and long-term phosphorus dynamics in a fertilized Ultisol under sugarcane. Soil Sci. Soc. Am. J., 57:1027:1034, 1993.

CASSOL, P.C.; GIANELLO, C. \& COSTA, V.E.U. Frações de fósforo em estrumes e sua eficiência como adubo fosfatado. R. Bras. Ci. Solo, 25:635-644, 2001. 
DJODJIC, F.; BÖRLING, K. \& BERGSTRÖM, L. Phosphorus leaching in relation to soil type and soil phosphorus content. J. Environ. Qual., 33:678-684, 2004.

DOU, Z.; TOTH, J.D.; GALLIGAN, D.T.; RAMBERG JR., C.F. \& FERGUSON, J.D. Laboratory procedures for characterizing manure phosphorus. J. Environ. Qual., 29:508-514, 2000.

EGHBALL, B. Soil properties as influenced by phosphorus and nitrogen - based manure and compost applications. Agron. J., 94:128-135, 2002.

EMPRESA BRASILEIRA DE PESQUISA AGROPECUÁRIA EMBRAPA. Centro Nacional de Pesquisa de Solos. Sistema brasileiro de classificação de solos. Brasília, Serviço de Produção de Informação, 1999. 412p.

GALVÃO, S.R.S.; SALCEDO, I.H. \& OLIVEIRA, F.F. Acumulação de nutrientes em solos arenosos adubados com esterco bovino. Pesq. Agropec. Bras., 43:99-105, 2008.

GRAETZ, D.A. \& NAIR, V.D. Fate of phosphorus in Florida Spodosols contamined with cattle manure. Ecol. Eng., 5:163-181, 1995.

HAO, X.; GODLINSKI, F. \& CHANG, C. Distribution of phosphorus forms in soil following long-term continuous and discontinuous cattle manure applications. Soil Sci. Soc. Am. J., 72:90-97, 2008.

HE, Z. \& HONEYCUTT, C.W. Enzymatic characterization of organic phosphorus in animal manure. J. Environ. Qual., 30:1685-1692, 2001.

HEDLEY, M.J.; STEWART, J.W.B. \& CHAUHAN, B.S Changes in inorganic and organic soil phosphorus fractions induced by cultivation practices and by laboratory incubations. Soil Sci. Soc. Am. J., 46:970-976, 1982.

HOUNTIN, J.A.; KARAN, A.; COUILLARD, D. \& CESCAS, M.P. Use $\mathrm{f}$ a fractionation procedure to assess the potential for $\mathrm{P}$ movement in a soil profile after 14 years of liquid pig manure fertilization. Agric. Ecosyst. Environ., 78:7784,2000 .

KLEINMAN, P.J.A.; WOLF, A.M.; SHARPLEY, A.N.; BEEGLE, D.B. \& SAPORITO, L.S. Survey of water extractable phosphorus in manures. Soil Sci. Soc. Am. J., 69:701-708, 2005.

KOOPMANS, G.F.; CHARDON, W.J. \& McDOWELL, R.W Phosphorus movement and speciation in a sandy soil profile after long-term animal manure applications. J. Environ. Qual., 36:305-315, 2007.

LEHMANN, J.Z.; LAN, Z.; HYLAND, C.; SATO, S.; SOLOMON, D. \& KETTERINGS, Q.M. Long-term dynamics of phosphorus forms and retention in manure-amended soils. Environ. Sci. Tecnol., 39:6672-6680, 2005.

LINDSAY, W.L. Chemical equilibria in soils. New York, John Wiley \& Sons, 1979. 449p.

MENEZES, R.S.C. \& SALCEDO. I.H. Mineralização de N após incorporação de adubos orgânicos em um Neossolo Regolítico cultivado com milho. R. Bras. Eng. Agric. Amb., 11:361-367, 2007.
MENEZES, R.S.C. \& OLIVEIRA, T.S. Mudanças na fertilidade de um Neossolo Regolítico após seis anos de adubação orgânica. R. Bras. Eng. Agric. Amb., 12:251-257, 2008.

MENEZES, R.S.C.; SALCEDO, I.H. \& ELLIOT, E.T. Microclimate and nutrient dynamics in a silvopastoral system of semiarid northeastern Brazil. Agroforestry Systems, 56:27-38, 2002.

MURPHY, J. \& RILEY, J.P. A. A modified simple solution method for the determination of phosphates in natural waters. Anal. Chim. Acta, 27:31-36, 1962.

NOVAIS, R.F. \& SMITH, T.J. Fósforo em solo e planta em condições tropicais. Viçosa, MG, Universidade Federal de Viçosa, 1999. 399p.

OHNO, T. \& ZIBILSKE, L.M. Determination of low concentrations of phosphorus in soil extracts using malachite green. Soil Sci. Soc. Am. J., 55:892-895, 1991.

R DEVELOPMENT CORE TEAM. R: A language and Environment for Statistical Computing. Vienna, R. Foundation for Statistical Computing, Vienna, 2008. Available at: <url: http://www.R-project.org>. Accessed on: March 03, 2008.

SABOURIN, E.; SILVEIRA, L.M.; TONNEAU, J.P. \& SIDERSKY, P. Fertilidade e agricultura familiar no Agreste Paraibano: Um estudo sobre o manejo da biomassa. Esperança, CIRAD-TERRA/ASPTA, 2000. 59p.

SALCEDO, I.H. Biogeoquímica do fósforo em solos da Região semi-árida do NE do Brasil. R. Geo., 23:108-123, 2007

SCHABENBERGER, O. \& PIERCE, F.J. Contemporary statistical models for the plant and soil sciences. Boca Raton, CRC Press, 2002. 925p.

SHARPLEY, A.N. \& MOYER, B. Phosphorus forms in manure and composts and their release during simulated rainfall. J. Environ. Qual., 29:1462-1469, 2000.

SHARPLEY, A.N.; McDOWELL, R.W. \& KLEINMAM, P.J.A. Amounts, forms, and solubility of phosphorus in soils receiving manure. Soil Sci. Soc. Am. J., 68:2048-2057, 2004.

SIDDIQUE, M.T. \& ROBINSON, J.S. Differences in phosphorus retention and release in soils amended with animal manures and sewage sludge. Soil Sci. Soc. Am. J., 68:1421-1428, 2004.

SILVA, T.O.; MENEZES, R.S.C.; TIESSEN, H.; SAMPAIO, E.V.S.B.; SALCEDO, I.H. \& SILVEIRA, L.M. Adubação orgânica da batata com esterco e/ou Crotalaria juncea. I - Produtividade vegetal e estoque de nutrientes no solo em longo prazo. R. Bras. Ci. Solo, 31:39-49, 2007.

SILVEIRA, M.M.L. Fracionamento seqüencial de fósforo em solos do semi-árido nordestino. Recife, Universidade Federal Rural de Pernambuco, 2000. 61p. (Tese de Mestrado)

SILVEIRA, M.M.L.; ARAÚJO, M.S.B. \& SAMPAIO, E.V.S.B. Distribuição de fósforo em diferentes ordens de solo do semi-árido da Paraíba e de Pernambuco. R. Bras. Ci. Solo, 30:281-291, 2006. 
SUE, J.; WANG, H.; KIMBERLEY, M.O.; BEECROFT, K.; MAGESAN, G.N. \& HU, C. Fractionation and mobility of phosphorus in a sandy soil amended biosolids. Environ. Sci. Poll. Res. 14:529-535, 2007.
TIESSEN, H.; SALCEDO, I.H. \& SAMPAIO, E.V.S.B. Nutrient and soil organic matter dynamics under shifting cultivation in semi-arid Northeastern Brazil. Agric. Ecosyst. Environ., 38:139-151, 1992. 